\title{
Circle hook versus J-hook: A case study of the Sultanate of Oman
}

${ }^{1}$ Ibrahim A. Al-Qartoubi, ${ }^{2}$ Shekar Bose,${ }^{3}$ Hussein S. Al-Masroori, ${ }^{3}$ Anesh Govender

$$
\text { الخطاف الدائري مقابل الحخطاف طويل الساق: دراسة حالة في سلطنة عمان }
$$

AbSTRACT. Improvement of harvesting efficiency and mitigation of undesirable environmental impacts of fishing gears are of considerable importance for achieving long term economic and environmental sustainability in fisheries. This paper analyses the operational efficiency and economic performance of the circle hook and the J-hook, commonly used by traditional fishers in the demersal longline fishery of the Sultanate of Oman. A longline experiment was conducted at three fishing locations at Masirah Island of Al-Sharqiyah Governorate. A total of 6,120 baited J-hooks and circle hooks were deployed over a 17-day period. The findings from this experimental research suggest that the overall performance (measured under various operational yardsticks such as hooking status and location, catch composition and quality, catching efficiency, and time and cost efficiency) of the circle hook is better than its counterpart. The results also indicate that the use of circle hooks has the potential to yield better financial returns. It is acknowledged that the reliance on three fishing locations may restrict the scientific generalizations. However, it is hoped that the results from this study will provide insight into the design of future experiments to ensure the validity of the present results and design effective management measures which will promote ecosystem-based approach to fishery management advocated by the FAO Code of Conduct for Responsible Fisheries.

KEYWORDS: operational efficiency; economic performance; longline fishery; traditional fishery

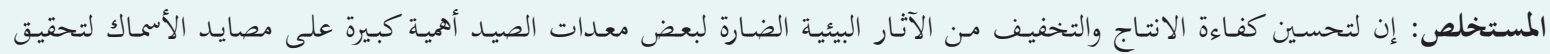

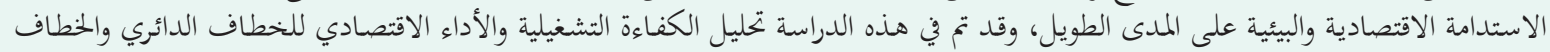

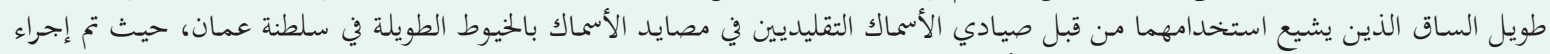

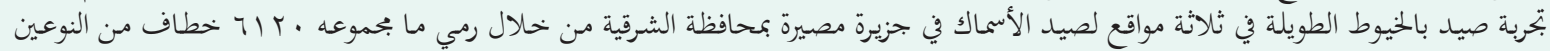

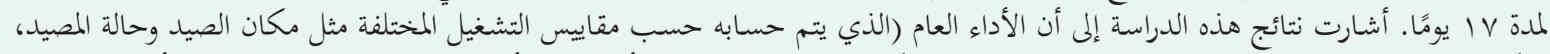

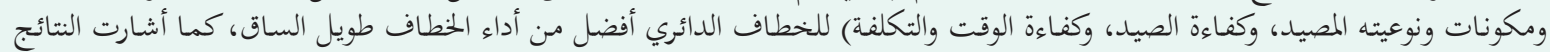

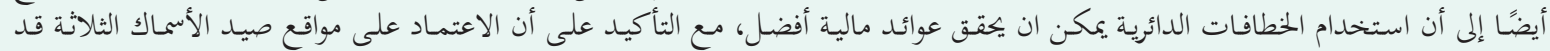

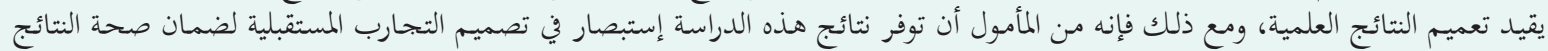

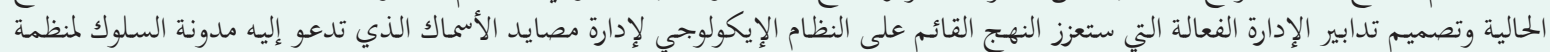

$$
\begin{aligned}
& \text { الأغذية والزراعة للصيد الرشيد. } \\
& \text { الكلمات المفتاحية: الكفاءة التشغيلية، الأداء الاقتصادي، مصايد الخيوط الطويلة، المصايد التقليدية }
\end{aligned}
$$

\section{Introduction}

W

ith rising concerns over conservation and sustainable utilization of fishery resources, there is a global impetus to mitigate harmful impacts of fishing gear on the marine environment and to improve harvest efficiency through modifications or the design of new fishing gears, and through technological innovation (Glass et al. 2007). Following the 'Code of Conduct for Responsible Fisheries' developed by the Food and Agriculture Organization of the United

\footnotetext{
$3^{*}$ Al-Masroori, Hussain $(\square)$ Department of Marine Science and Fisheries, College of Agricultural and Marine Sciences, Sultan Qaboos University, P.O. Box 34, Postal Code 123, Sultanate of Oman, email: masroori@squ.edu.om. ${ }^{1}$ Ministry of Agriculture and Fisheries, P.O. Box 427 , Postal Code 100, Sultanate of Oman. ${ }^{2}$ Department of Natural Resource Economics, College of Agricultural and Marine Sciences, Sultan Qaboos University, P.O. Box 34, Postal Code 123, Sultanate of Oman.
}

Nations (FAO, 1995), Bjordal (2002) characterized the ideal fishing gear by using criteria such as high selectivity of target species, relatively low impact on non-target species and habitat, cost efficiency and product quality, amongst others. In this context, research on fishing gear

It is evident from the past research that the performance of circle hooks is better than that of J hooks (Prince et al. 2002; Kerstetter \& Graves, 2006; Pacheco et al. 2011; Andraka et al. 2013; Huang et al. 2016). For example, a study by Prince et al. (2002) evaluated the performance of circle and J hooks with the aid of indicators such as fishing success, hook location, physical damage and trauma on mainly Atlantic and Pacific sailfish. It was found that in terms of fishing success (fish hooked/ bite), hook location (minimized deep hooking and foul hooking) and physical damage (minimize hook-related bleeding) circle hooks performed better than of J hooks. In a comparative performance evaluation of circle hook 
and J hook using performance indicators such as catch composition, catch rates, hooking location, and status at release in a commercial Atlantic Ocean pelagic longline fishery. Pacheco et al. (2011) suggested that the use of circle hooks, in comparison with J hooks, has the potential to reduce fishing mortality of by catch species with minimal effects on the target species catch. In analyzing the performance of circle hooks in relation to J hooks and tune hooks based on the hooking rates of target and non-target species in the artisanal longline fisheries of Ecuador, Panama, and Costa Rica, Andraka et al. (2013) noted that sea turtle hooking rates were lower in case of circle hooks. Based on a review of recent research Huang et al. (2016) pointed out a potential conservation value as the shape of circle hooks contributes to the minimization of foul-hooking and injury to both fishes and bycatch species. In a study on the U.S. Atlantic coastal pelagic longline fishery that involves target (tuna and swordfish) and non-target species (billfish and sea turtles) Kerstetter \& Graves (2006) noted that the use of circle hooks not only improved the survival of the non-target species but also had minimum effects on the catches of target species.

The present paper evaluated this hypothesis for the case of a traditional small-scale fishery using hook status, catch composition and quality, hooking location, time and cost efficiency as performance indicators. It also extended this hypothesis by adding an economic indicator (i.e., gross economic benefits) and hypothesize that the use of circle hooks has the potential to yield better financial returns to fishers compared to J hooks.

Considering this significance of research on fishing gear and designs, the main objective of this study is to analyse the operational efficiency, and economic performance of the J-hook and the circle hook used in the demersal longline fishery of Oman. In the context of Oman, there is a dearth of research on this subject matter and the basic information on such fishing practices is limited. Therefore, an appraisal of various aspects of operational efficiency of the selected fishing gear should provide vital information to the process of recommending environmentally friendly fishing gear, enhancing fishing efficiency through refinements, improving catch quality, and making informed management decisions for effective management of fisheries resources.

\section{Longline fishing and related ele- ments}

Fisheries is an integral part of the traditional way of life in Oman and the traditional sector that refers to groups of small-scale fishermen employing a variety of traditional fishing gear and vessels (Al-Masroori et al. 2004) has been the dominant both in terms of total landings and value (about $86 \%$ in 1985-2013). In addition, the traditional sector provides direct employment (both fulland part-time) of 44,521 fishermen (MAF, 2013).
In Oman, longline fishing has been divided into two categories namely, traditional and industrial longlining. The industrial fishing by pelagic longliners began in Oman in 1989 and is mainly used to catch tuna and swordfish. These are steel vessels that can range in length from 40 to $60 \mathrm{~m}$, and they fish in the high seas at distances of more than 20 nautical miles offshore. As part of the traditional category, demersal longlining (locally termed as AlShakah) is practiced by traditional fishers (MAF 2002) and the subsequent catch typically comprises of grouper (Epinephelus sp., Cephalopholis sp.), emperor (Lethrinus sp.), snapper (Lutjanus sp.), thicklip (Plectorhinchus sp.), and sea bream (Argyrops sp., Acanthopagrus sp.), amongst other species. The demersal longline consists of a mainline, branchlines and hooks in between two floats. The mainline is usually several hundred metres in length, with a diameter commonly ranging from $0.5 \mathrm{~cm}$ to $1 \mathrm{~cm}$ and is made of various types of multifilament (cotton, nylon, polyester or polypropylene) and monofilament (polyamide, nylon) materials. The most common hooks used in Omani demersal longline fisheries are the J-hook and the circle hook. However, it is noted that the circle hook has gained popularity despite a comparatively higher cost (2-3 times higher) associated with its use $^{1}$. This popularity of circle hook could be due to a higher catch rate and better catch quality experienced by fishers compare to the traditional J-hook (Stengel and Al-Harthy, 2001). The demersal longline fishing is mostly carried out with the use of Fiberglass Reinforced Plastic (FRP)-fishing boats. Fishers use mackerel, sardine, cuttlefish and squid as bait which may be fresh, frozen or salted.

The hook is central to longline fishing which consists of a shank, bend, point, barb and an eye (or ring) for attaching it to the branch line. The hook performs two functions: catching the fish and retaining it until it is safely landed on board the boat. The catching efficiency of a longline is defined as the proportion of target or commercial fish that are caught per unit number of baited hooks set. The daily catch (C) of a longline is therefore defined by the number of hooks that are set and hauled per day and can be expressed by the following equation (Bjordal \& Lokkeborg 1996):

\begin{tabular}{|l|l|}
\hline$C=n a_{1}\left(1-a_{2}\right)\left(1-a_{3}\right)\left(1-a_{4}\right) a_{5} w$ & $e q(1)$ \\
\hline
\end{tabular}

where, $\mathrm{n}=$ number of hooks set and hauled per day, $a_{1}=$ proportion of hooks leaving the vessel with bait on, $a_{2}=$ proportion of hooks with bait loss caused by sea birds, $a_{3}=$ proportion of hooks with bait loss due to seabed scavengers, $a_{4}$ =proportion of hooks with bait loss due to small fish or non-target species that eat the bait without being hooked, $a_{5}=$ catching (hooking and retention) ${ }^{1}$ A box of 100 Mustad size 6 common longline J-hook, costs approximately OMR 3 (depending on the number and location of purchase) while the same quantity of equivalent sized number $6 / 0$ circle hooks might cost from OMR 6 to 9 (1 Rial =US \$2.58). 
Various factors influence the catching efficiency namely, hook spacing and density of target species (Bjordal \& Lokkeborg 1996; Skud \& Hamley 1978), bait type, quality and size (Bach et al. 2000; Johannessen et al. 1993), hook design (Radcliffe 2005), size of the hook, which is measured by gap width, shank length and wire dimension (Garry et al. 1999; Bjordal and Lokkeborg 1996), material of the hook (iron, stainless steel), shape of the point, hook finish (colour and coating), and environmental factors such as tide, current, light, moon phase and the nature of the sea bed (ICES 1977). Martian and McCracken (1954) found that bait size had a significant effect on catching efficiency, and longline experiments have demonstrated very different rates of effectiveness of squid, mackerel and herring for catching demersal fish. Halliday and Kenchington (1993) concluded that since the power of attraction is directly related to the size of the bait, it is important in selectivity studies to use a standard bait size. The wide gap hook with a very fine turned in point may be more successful in penetrating the inner mouth parts than a more conventional hook. Research done by Skud (1978), Lokkeborg and Bjordal (1992) and Bjordal and Lokkeborg (1996) found that smaller hooks give higher catch rates than larger hooks.

In comparison with other frequently used fishing gear, the popularity of demersal longlining as mentioned in the literature, was due to economic efficiency labelled as lower cost per unit effort (Cai et al. 2005), catching effectiveness (He et al. 1997), delivery of better quality products (Lokkeborg \& Bjordal 1992), less fuel consumption (Bjordal 1988), good species selective properties through the selection of hook type, bait type and fishing depth and ground (Clarke et al. 2002), and little or no destructive impact on bottom habitats (Hareide 1995).

\section{Materials and Methods}

A longline fishing experiment was carried out at Ra's Abu Rasas, south of Masirah Island (see Figure 1 for study location) from 2-23 December, 2004. The fishing ground Ra's Abu Rasas, was chosen for the experiment on the basis of familiarity gained by the first author through previous fishing experience, and access to local fishermen knowledge about the fishing ground which is essential for a successful deployment of the gear. Other variables such as depth, distance between locations, and proximity were also considered in selection. The experiments were conducted on-board a small FRP (Fibre Reinforced Plastic) fishing boat, measuring $9 \mathrm{~m}$ long $\times 2.5$ $\mathrm{m}$ wide $\times 0.8 \mathrm{~m}$ draft, propelled by two $60 \mathrm{HP}$ outboard Mariner engines. On-board fish finder and Global Positioning System (GPS) were used to decide on the fishing locations within Ra's Abu Rasas for deployment of the

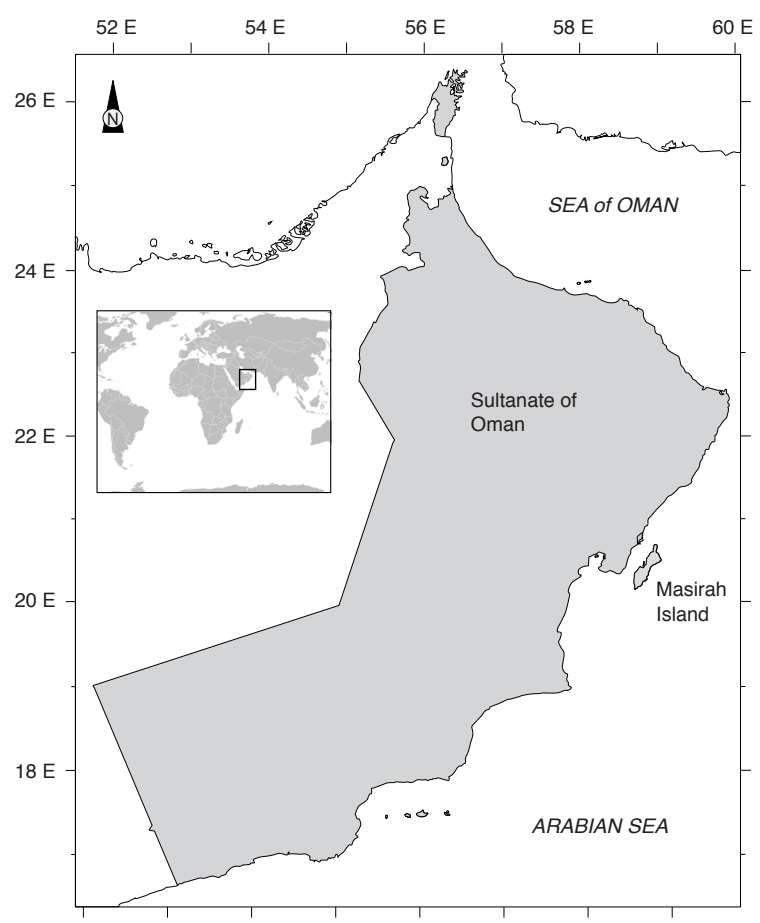

Figure 1. Map of Sultanate of Oman including with the sampling (Masirah Island) (source: MNE. 2004).

fishing gear. Three locations (1, 2 and 3), 2 to 4 nautical miles (nm) apart from each other, were selected with average depths of 50, 22 and $10 \mathrm{~m}$ respectively (Figure 1). The the seabed was characterised by patches of rocks, sand and coral (Stengel and Al-Harthy, 2001). Given their close proximity and similar seabed characteristics, it was assumed that the three locations were similar with respect to fish abundance. Each location was given a number from one to three and a location was randomly selected every day. For all three locations the same fishing gear was engaged throughout the study period.

A total of six demersal longlines were used daily in the experiment. Each longline consisted of a $124 \mathrm{~m}$ polyester (PES) multifilament main line with a diameter of 0.4 $\mathrm{cm}$. Sixty monofilament branch lines were connected to each mainline via a number $2 / 0$ swivel to prevent the fish rotating and tangling the branch line and the mainline. The length of each branch line was $80 \mathrm{~cm}$ with a $0.1 \mathrm{~cm}$ diameter. Each branch line was attached to the mainline $2 \mathrm{~m}$ apart and hence, hook spacing was also $2 \mathrm{~m}$. At the end of each branch line there was either a circle hook or a J-hook, thus a total of 60 hooks per basket were used in the experiment. The features of the hooks used in the experiment are as follows: the J-hook size no. 6 (Mustad, Ref: 2335DT, Key brand, made in Norway) and the circle hook size no. 6/0 (Mustu Hooks, Maruto fish hook works, Quality No. 350, Superior Steel, Eagle Wave brand, made in Japan). These types of hooks are commonly used by the traditional fishers to catch demersal 
species in Oman. The J-hook was $5.3 \mathrm{~cm}$ in length with a $1.9 \mathrm{~cm}$ wide gap and the circle hook was $3.5 \mathrm{~cm}$ in length with a $1.4 \mathrm{~cm}$ wide gap. A $25 \mathrm{~m}$ polyethylene (PE) buoy line with a diameter of $0.8 \mathrm{~cm}$ was used. Around $3 \mathrm{~kg}$ of weight was used as a sinker at each end of the main line.

A total of 3,060 J-hooks and 3,060 circle hooks were deployed over 17 days. Each morning, 180 J-hooks and 180 circle hooks were deployed from six baskets in the selected location. Across all three fishing locations an equal number of circle and J-hooks were randomly deployed each day. Over the duration of the study $41.2 \%$ of the total number of hooks was deployed at location 1 and 29.4\% were deployed at each of locations 2 and 3.

Each of the six baskets was given a number from one to six along with hook types for ease of identification. Each day of the experiment, the basket was selected in a random manner to avoid hook-selection bias. Frozen cuttlefish (Sepia spp.) was used as bait weighing about $10 \mathrm{~g}$. Each evening the hooks were baited for the following day's fishing experiment, and the baited longline was then refrigerated overnight. The longline set was deployed and hauled by hand in the direction of the prevailing tides. It was assumed that the bait-plume from one longline would not influence the attractiveness of any adjacent longline within the same fishing location. The experiments were usually conducted between 07:25 am and 12:00 noon, which is the normal operation time for coastal fishing boats at Masirah Island. The demersal longlines were set in the morning and the soak times for all experiments were two hours (a typical soak time for the coastal boats in Omani waters).

When a longline was hauled, each caught fish was recorded in terms of weight $(\mathrm{kg})$, total length $(\mathrm{cm})$, species (common and scientific name) and hook location. Information on hook status (e.g. hooks missing, damaged), gear condition (e.g. main line and branch line loss or damaged) and bait condition (loss, return) was also recorded for each set. Hooking locations were designated using the following terminology: corner of the mouth, jaw (upper and lower), gill, gut, eye and body. Additional information was also recorded such as fishing location (longitude, latitude, depth, and bottom characteristic), weather conditions, and operation time (deployment and hauling time).

Experimental data gathered from the three locations were analysed for individual location and for all location as a group. Total catches were standardized to daily catch per unit of effort (CPUE), defined as the number of fish caught per 100 hooks retrieved (no. of fish/100 hooks retrieved). Appropriate test statistics (i.e. $\chi^{2}$ test, F-test, Tukey's Post Hoc Test) and analytical methods (i.e., ANCOVA) were used to examine various relevant hypotheses using the SPSS software. Considering the catch composition and species current market status, only for commercial species and dominant family category cases were statisticaly

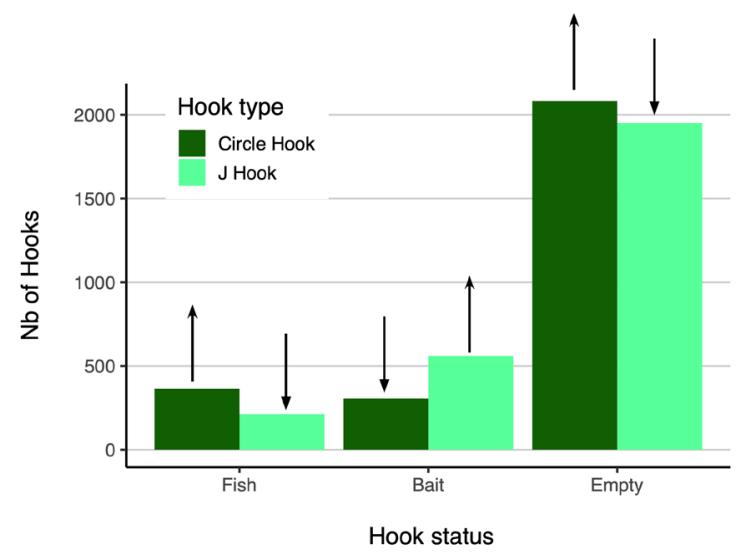

Figure 2. Hook status by hook type. Hook status describes a retrieved hook either with fish (commercial and non-commercial) attached, only bait attached or empty (bait removed). The arrows indicate the outcome of Chisquare analysis of hook status where the observed number of hook was less (down arrow) or more (up arrow) than expected.

\section{Results}

This section provides both location-specific and combined analytical results where relevant with particular reference to yardsticks used namely hook status, catch composition, hooking location, catch efficiency for total, commercial and dominant family species, gross financial returns from commercial species catch, and time efficiency.

\section{Hook status: retrieval and loss}

Of the total number of hooks deployed, approximately $10 \%$ of the gear involving both hook types was lost. About $5 \%$ of the total loss was assigned to missing sections of the mainline, while $24 \%$ was due to broken branch lines and the remainder was due to missing hooks. Due to gear loss or damage, $90 \%$ of the circle hooks and $89 \%$ of the J-hooks were retrieved.

A significant difference in hook status by hook types is noted $\left(X^{2}=123.698, \mathrm{df}=2, \mathrm{p}<0.001\right)$, with more circle hooks retrieved with fish and less circle hooks with bait attached. Figure 2 depicts the hook retrievals by hook types with fish, bait, and without fish and bait. The proportion of hook status was comparatively higher for empty category for both hook types (Fig. 2). In addition, statistical differences in the proportion of hooks with regard to hook status (i.e. empty, bait only, or fish) was detected among fishing locations $\left(x^{2}=502.376\right.$, df $4, \mathrm{p}<0.001)$. The proportion of retrieved hooks with bait attached was more for both hook types in location 2 and the proportion of empty hooks was less for both hook types at the same location. The highest proportion of retrieved circle hooks with fish attached (14.8\%) was recorded in location 3 . It is noted that hook losses 
Table 1. Catch composition by hook type.

\begin{tabular}{|c|c|c|c|c|c|}
\hline S.No & Family name & Scientific name & Common name & \multicolumn{2}{|c|}{ Fish number } \\
\hline \multicolumn{2}{|c|}{ Commercial species } & & & J-hook & Circle hook \\
\hline 1 & Arridae & Arius bilineatus & Roundsnot sea catfish & 3 & 0 \\
\hline 2 & Haemulidae & Plectorhinchus pictus & Trout thicklip & 13 & 22 \\
\hline 3 & Haemulidae & Plectorhinchus gibbosus & Dusky thicklip & 1 & 5 \\
\hline 4 & Hemigaleidae & Paragaleus sp. & Arabian weasel shark & 44 & 4 \\
\hline 5 & Lethrinidae & Lethrinus microdon & Spangled emperor & 68 & 188 \\
\hline 6 & Lethrinidae & Lethrinus nebulosus & Smalltooth emperor & 16 & 23 \\
\hline 7 & Lethrinidae & Lethrinus lentjan & Redspot emperor & 26 & 38 \\
\hline 8 & Lutjanidae & Lutjanus coeruleolineatus & Bluelined snapper & 0 & 13 \\
\hline 9 & Lutjanidae & Lutjanus russelli & Russell's snapper & 1 & 3 \\
\hline 10 & Serranidae & Epinephelus stoliczkae & Epaulet grouper & 8 & 8 \\
\hline 11 & Serranidae & Epinephelus areolatus & Areolate grouper & 1 & 8 \\
\hline 12 & Serranidae & Epinephelus diacanthus & Spinycheek grouper & 0 & 1 \\
\hline 13 & Sparidae & Argyrops spinifer & King soldier bream & 13 & 30 \\
\hline 14 & Sparidae & Rhabdosargus sarba & Gold striped seabream & 1 & 0 \\
\hline \multicolumn{6}{|c|}{ Non-commercial species } \\
\hline 1 & Balistdae & Sufflamen frarnatus & Bridled triggerfish & 7 & 9 \\
\hline 2 & Diodontidae & Diodon hystrix & Porcupine fish & 2 & 2 \\
\hline 3 & Muraenidae & Siderea flavocula & Palenose moray & 6 & 14 \\
\hline 4 & Stegostomatidae & Stegostoma varium & Zebra shark & 3 & 0 \\
\hline
\end{tabular}

were similar among the three fishing locations and no significant difference was observed between locations $\left(\mathrm{x}^{2}=4.363\right.$, df $\left.4, \mathrm{p}=0.359\right)$.

\section{Catch composition}

There were total of 18 (14 commercial and 4 non-commercial) species in the observed catch consisting of 11 families (7 commercial and 4 non-commercial) (Table 1). Circle hooks caught 9 families whereas the J-hook caught all 11 families. Catches with both types of hooks were dominated by family Lethrinidiae and three species namely, Lethrinus microdon, Lethrinus nebulosus and Lethrinus lentjan. These 3 species together accounted for $53 \%$ and $62 \%$ of the total commercial catch by weight and number respectively. Catches of both hook types were dominated by Lethrinus microdon, which accounted for $38 \%$ and $48 \%$ of the total catch by weight and number respectively.

\section{Hooking location}

Of the total catch of commercial and non-commercial fish by both hook types, $65 \%$ of the fish were hooked in the corner of the mouth, $19 \%$ were hooked in the jaw, $11 \%$ were hooked in the gill, and 5\% were hooked in the gut (Fig. 3). There was a significant difference in hooking location for the total catch between hook types $\left(\chi^{2}=\right.$
$291.338, \mathrm{df}=3, \mathrm{p}<0.001)$. Approximately $90 \%$ of the total catch caught by the circle hook was hooked in the corner of the mouth and $21 \%$ were hooked in the similar position by J-hooks. The proportion of fish hooked in the jaw

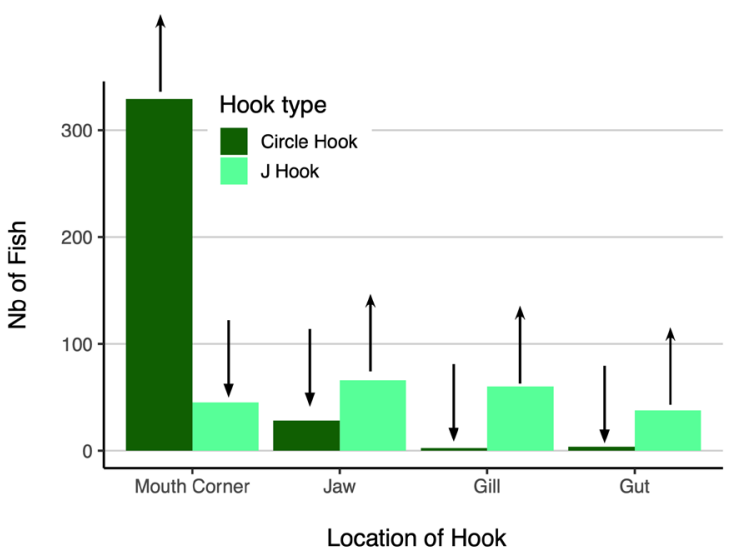

Figure 3. The observed number of fish caught in each hooking location by hook type. The arrows indicate the outcome of Chi-square analysis where the observed number of fish was less (down arrow) or more (up arrow) than expected. 
and gill using the J-hook was $38 \%$ and $29 \%$ respectively. There was a significant difference $\left(x^{2}=15.708, \mathrm{df}=6\right.$, $\mathrm{p}<0.015)$ in hooking location for the total catch with respect to fishing location, with a greater number of fish being hooked in the gill by both hook types at location 1 and a greater than expected number being hooked in the jaw at location 2 .

With respect to commercial species, there was a significant difference $\left(x^{2}=248.49, \mathrm{df}=3, \mathrm{p}<0.001\right)$ in the hooking location by hook type but no significant difference was found $\left(x^{2}=12.05, \mathrm{df}=6, \mathrm{p}<0.061\right)$ in hooking location

Table 2. Total combined catch weight and number $(+/-\mathrm{se})$ at each fishing location by hook type.

\begin{tabular}{|c|c|c|c|c|c|c|}
\hline $\begin{array}{c}\text { Loca- } \\
\text { tion }\end{array}$ & $\begin{array}{l}\text { Hook } \\
\text { type }\end{array}$ & $\begin{array}{c}\text { Number } \\
\text { of fish }\end{array}$ & $\begin{array}{l}\text { Weight } \\
\text { (kg) }\end{array}$ & $\begin{array}{l}\text { Weight } \\
(\%)\end{array}$ & $\begin{array}{l}\text { Average } \\
\text { Weight }\end{array}$ & SE \\
\hline \multirow[b]{2}{*}{1} & J-hook & 93 & 184.4 & 40.5 & 2.0 & 0.35 \\
\hline & $\begin{array}{l}\text { Circle } \\
\text { hook }\end{array}$ & 157 & 181.5 & 38.7 & 1.2 & 0.08 \\
\hline \multirow[b]{2}{*}{2} & J-hook & 46 & 97.9 & 21.5 & 2.1 & 0.17 \\
\hline & $\begin{array}{l}\text { Circle } \\
\text { hook }\end{array}$ & 93 & 134.4 & 28.7 & 1.4 & 0.13 \\
\hline \multirow[b]{2}{*}{3} & J-hook & 74 & 173.4 & 38.1 & 2.3 & 0.52 \\
\hline & $\begin{array}{l}\text { Circle } \\
\text { hook }\end{array}$ & 118 & 152.6 & 32.6 & 1.3 & 0.09 \\
\hline \multirow[b]{2}{*}{ Total } & J-hook & 213 & 455.7 & 100.0 & 2.1 & 0.23 \\
\hline & $\begin{array}{l}\text { Circle } \\
\text { hook }\end{array}$ & 368 & 468.5 & 100.0 & 1.3 & 0.10 \\
\hline
\end{tabular}

with fishing locations. With respect to the dominant family (Lethrinidae), there was a significant difference in hooking location by hook types $\left(X^{2}=153.896, \mathrm{df}=3\right.$, $\mathrm{p}<0.001$ ), with a greater number of catch being hooked in the corner of the mouth by the circle hook and a greater than expected number being hooked in the gut by the J-hook. Over $97 \%$ of the total catch of Lethrinidae by the circle hook was hooked in the corner of the mouth, but only $29 \%$ were hooked in this same position by the J-hook. Of the total catches of Lethrinidae by both hook types, around $71 \%$ were hooked in the corner of the mouth, $11 \%$ were hooked in the jaw, $13 \%$ were hooked in the gill and less than $5 \%$ were hooked in the gut. A significant difference $\left(\mathrm{X}^{2}=16.318, \mathrm{df}=6, \mathrm{p}<0.012\right)$ was also found in hooking location for the Lethrinidae catch by fishing location. In relation to the dominant species ( $L e$ thrinus microdon), a significant difference $\left(\chi^{2}=89.807\right.$, $\mathrm{df}=3, \mathrm{p}<0.001)$ was noted in the hooking location for Lethrinus microdon by hook type but the same does not hold for fishing location $\left(x^{2}=9.54, \mathrm{df} 6, \mathrm{p}<0.145\right)$.

\section{Catching efficiency}

\section{Total catch}

The average catching efficiency ( \pm standard error) measured by equation (1) for the circle hook and the J-hook was $17.1 \pm 2.0 \mathrm{~kg}$ and $16.7 \pm 3.0 \mathrm{~kg}$ per 100 hooks retrieved, respectively. There was no significant difference in the mean catching efficiency of the total catch between hook type ( ANOVA: F value $=0.001, \mathrm{df}=1,96, \mathrm{p}<0.976$ ) Also, the difference in mean catching efficiency between hook type and location was not significant (ANOVA: $\mathrm{F}_{\text {(hook type*locations) }}=0.002, \mathrm{df}=2,96 \mathrm{p}<0.998$ ). However, there was a significant difference in the mean catching efficiency for the total catch between the three fishing locations (ANOVA: $\mathrm{F}=4.367, \mathrm{df}=2,96, \mathrm{p}<0.015$ ). Furthermore, the Tukey's HSD showed that this difference was significant between locations 1 and $2(\mathrm{p}<0.013)$.

A total of 581 fish were caught by the J-hook and circle hook with a combined total weight of $924.3 \mathrm{~kg}$. The circle hook caught $50.7 \%$ of the total catch weight and $63 \%$ of the total catch number (Table 2 ). There was a significant difference in the total catch weight by hook type (ANCOVA: $\mathrm{F}=16.312, \mathrm{df}=1,574, \mathrm{p}<0.001$ ). The average catch per day was not affected by the difference in fishing days among the locations (ANCOVA: $\mathrm{F}=0.181$, df $1,574, \mathrm{p}=0.670)$ and the difference in average catch per day between hook type and location was not significant (ANCOVA: $\mathrm{F}$ (hook type*location) $=0.278, \mathrm{df}=2,574 \mathrm{p}$ $<0.757$ ). There was no significant difference (ANCOVA: $\mathrm{F}=0.694, \mathrm{df}=2,574, \mathrm{p}<0.500)$ in the total catch mean weight by fishing locations.

There was a significant difference in length frequency distribution of the total catch between the two hook types $\left(x^{2}=67.229, \mathrm{df}=4, \mathrm{p}<0.001\right)$, with fish $>60 \mathrm{~cm}$ more likely to be caught using the J-hook than the circle hook and the circle hook more likely to have caught more small fish. There was also a significant difference $\left(\mathrm{X}^{2}=32.240, \mathrm{df}=8, \mathrm{p}<0.001\right)$ in length frequency distributions for the total catch among the fishing locations, with more small fish $(<31 \mathrm{~cm})$ caught by both hook types at location 1 and more than expected large fish $(>91 \mathrm{~cm})$ caught at location 2 .

\section{Commercial catch}

There was no significant difference in the mean catching efficiency of total commercial catch by hook type (ANOVA: $F=0.001, \mathrm{df}=1,96, \mathrm{p}<0.975)$. Also, the difference in mean catching efficiency between hook type and location was not significant (ANOVA: F (hook type"locations) $=0.004, \mathrm{df}=2,96, \mathrm{p}<0.996)$. However, there was a significant difference in the mean catching efficiency for the total commercial catch between the three fishing locations (ANOVA: $\mathrm{F}=8.004, \mathrm{df}=2,96, \mathrm{p}<0.001$ ). Furthermore, the Tukey's Post Hoc Test showed that this difference was significant between locations 1 and 2 ( $p$ $<0.001)$ and location 1 and $3(\mathrm{p}<0.007)$. However, there were no significant differences noted in mean catch between location 2 and 3.

The commercial catch comprised $88 \%$ by weight and $92.6 \%$ by number of the total catch. There was a significant difference in catch weight by hook type (ANCOVA: $\mathrm{F}=8.800, \mathrm{df}=1,531, \mathrm{p}<0.003)$. The circle hook caught $94.7 \%$ by weight and $93.2 \%$ by number of the total combined catch (commercial and non-commercial). The difference in the number of fishing days among the loca- 
Table 3. Average price, catch weight, and gross value of species caught using J-hook and circle hook at different locations.

\begin{tabular}{|c|c|c|c|c|c|c|c|c|c|c|c|c|c|c|c|c|c|}
\hline \multirow{3}{*}{ Species } & \multirow{3}{*}{$\begin{array}{l}\text { Ave. } \\
\text { Price } \\
\text { OMR }\end{array}$} & \multicolumn{4}{|c|}{ Locaton 1} & \multicolumn{4}{|c|}{ Location 2} & \multicolumn{4}{|c|}{ Location 3} & \multicolumn{4}{|c|}{ Total } \\
\hline & & \multicolumn{2}{|c|}{ J-hook } & \multicolumn{2}{|c|}{ circle hook } & \multicolumn{2}{|c|}{ J-hook } & \multicolumn{2}{|c|}{ circle hook } & \multicolumn{2}{|c|}{ J-hook } & \multicolumn{2}{|c|}{ circle hook } & \multicolumn{2}{|c|}{ J-hook } & \multicolumn{2}{|c|}{ circle hook } \\
\hline & & $\begin{array}{l}\text { Wt. } \\
(\mathrm{kg})\end{array}$ & $\begin{array}{l}\text { Value } \\
\text { (R.O) }\end{array}$ & $\begin{array}{l}\text { Wt. } \\
(\mathrm{kg})\end{array}$ & $\begin{array}{l}\text { Value } \\
\text { (R.O) }\end{array}$ & $\begin{array}{l}\text { Wt. } \\
\text { (kg) }\end{array}$ & $\begin{array}{l}\text { Value } \\
\text { (R.O) }\end{array}$ & $\begin{array}{l}\text { Wt. } \\
(\mathrm{kg})\end{array}$ & $\begin{array}{l}\text { Value } \\
\text { (R.O) }\end{array}$ & $\begin{array}{l}\text { Wt. } \\
(\mathrm{kg})\end{array}$ & $\begin{array}{l}\text { Value } \\
\text { (R.O) }\end{array}$ & $\begin{array}{l}\text { Wt. } \\
(\mathrm{kg})\end{array}$ & $\begin{array}{l}\text { Value } \\
\text { (R.O) }\end{array}$ & $\begin{array}{l}\text { Wt. } \\
(\mathrm{kg})\end{array}$ & $\begin{array}{l}\text { Value } \\
\text { (R.O) }\end{array}$ & $\begin{array}{l}\text { Wt. } \\
(\mathrm{kg})\end{array}$ & $\begin{array}{l}\text { Value } \\
\text { (R.O) }\end{array}$ \\
\hline L. microdon & 0.49 & 55.2 & 27.0 & 71.0 & 34.8 & 34.5 & 16.9 & 68.2 & 33.4 & 16.7 & 8.2 & 61.3 & 30.0 & 106.4 & 52.1 & 200.5 & 98.2 \\
\hline L. nebulosus & 0.49 & 27.5 & 13.5 & 16.7 & 8.2 & 18.5 & 9.1 & 24.0 & 11.8 & 6.5 & 3.2 & 22.7 & 11.1 & 52.5 & 25.7 & 63.4 & 31.1 \\
\hline P. pictus & 0.55 & 9.0 & 5.0 & 22.0 & 12.1 & 19.0 & 10.5 & 13.1 & 7.2 & 8.5 & 4.7 & 20.2 & 11.1 & 36.5 & 20.1 & 55.3 & 30.4 \\
\hline A. spinifer & 0.50 & 11.5 & 5.8 & 14.8 & 7.4 & 10.5 & 5.3 & 18.0 & 9.0 & 7.5 & 3.8 & 19.7 & 9.9 & 29.5 & 14.8 & 52.5 & 26.3 \\
\hline L. lentjan & 0.49 & 21.3 & 10.4 & 22.8 & 11.1 & 0.0 & 0.0 & 1.6 & 0.8 & 10.0 & 4.9 & 7.2 & 3.5 & 31.3 & 15.3 & 31.5 & 15.4 \\
\hline P. gibbosus & 0.55 & 0.0 & 0.0 & 6.0 & 3.3 & 3.5 & 1.9 & 0.0 & 0.0 & 0.0 & 0.0 & 8.0 & 4.4 & 3.5 & 1.9 & 14.0 & 7.7 \\
\hline A. bilineatus & 0.13 & 4.5 & 0.6 & 0.0 & 0.0 & 0.0 & 0.0 & 0.0 & 0.0 & 7.5 & 1.0 & 0.0 & 0.0 & 12.0 & 1.6 & 0.0 & 0.0 \\
\hline E. stoliczkae & 0.59 & 1.5 & 0.9 & 1.1 & 0.6 & 0.7 & 0.4 & 0.2 & 0.1 & 1.3 & 0.8 & 2.4 & 1.4 & 3.5 & 2.1 & 3.7 & 2.2 \\
\hline E. areolatus & 0.59 & 0.5 & 0.3 & 6.1 & 3.6 & 0.0 & 0.0 & 0.0 & 0.0 & 0.0 & 0.0 & 0.0 & 0.0 & 0.5 & 0.3 & 6.1 & 3.6 \\
\hline L.coeruleolineatus & 0.67 & 0.0 & 0.0 & 2.5 & 1.7 & 0.0 & 0.0 & 2.0 & 1.3 & 0.0 & 0.0 & 2.0 & 1.3 & 0.0 & 0.0 & 6.5 & 4.4 \\
\hline R. sarba & 0.50 & 1.0 & 0.5 & 0.0 & 0.0 & 0.0 & 0.0 & 0.0 & 0.0 & 0.0 & 0.0 & 0.0 & 0.0 & 1.0 & 0.5 & 0.0 & 0.0 \\
\hline L. russelli & 0.67 & 0.0 & 0.0 & 0.0 & 0.0 & 0.0 & 0.0 & 0.1 & 0.1 & 0.3 & 0.2 & 0.2 & 0.1 & 0.3 & 0.2 & 0.3 & 0.2 \\
\hline E. diacanthus & 0.59 & 0.0 & 0.0 & 0.2 & 0.1 & 0.0 & 0.0 & 0.0 & 0.0 & 0.0 & 0.0 & 0.0 & 0.0 & 0.0 & 0.0 & 0.2 & 0.1 \\
\hline Total & & 132.0 & 64.0 & 163.2 & 82.9 & 86.7 & 44.0 & 127.2 & 63.7 & 58.3 & 26.8 & 143.7 & 72.8 & 277.0 & 134.6 & 434.0 & 219.6 \\
\hline Price per kg & & 0.48 & & 0.51 & & 0.51 & & 0.50 & & 0.46 & & 0.51 & & 0.49 & & 0.51 & \\
\hline
\end{tabular}

tions did not affect the average catch per day (ANCOVA: $\mathrm{F}=1.644, \mathrm{df}=1,531, \mathrm{p}<0.200)$. The difference in average total commercial catch per day between the two hook types was the same at all locations (ANCOVA: F (hook type"location) $=2.395, \mathrm{df}=2,531, \mathrm{p}<0.092)$. There was no significant difference (ANCOVA: $F=2.646, \mathrm{df}=1,531, \mathrm{p}$ $<0.072$ ) in the total commercial catch weight by fishing locations. The circle hook caught $54.5 \%$ by weight and $63.8 \%$ by number, of the total combined commercial catch.

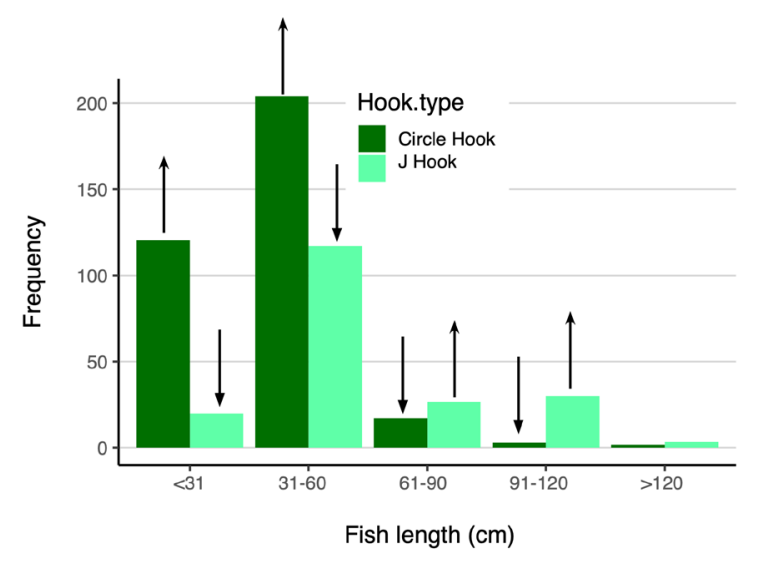

Figure 4. Length frequency of the commercial catch by hook type. The arrows indicate length frequency where the observed numbers were less (down arrow) or more (up arrow) than expected.
In all three fishing locations and for both hook types, $60 \%$ of the commercial catch measured between $31-60$ $\mathrm{cm}, 26 \%$ were $<31 \mathrm{~cm}$ and $14 \%$ were $>60 \mathrm{~cm}$ (Figure 4). Between hook types the length frequency distributions of the commercial catch were significantly different $\left(\chi^{2}\right.$ $=70.880, \mathrm{df}=4, \mathrm{P}<0.001)$. Circle hooks caught more than expected fish in the $31-60 \mathrm{~cm}$ size class. Fish larger than $60 \mathrm{~cm}$ were more likely to be caught using the J-hook than the circle hook and the circle hook caught more of the smaller fish.

\section{Dominant family (Lethrinidae)}

There was no significant difference (ANOVA: $\mathrm{F}=0.001$, $\mathrm{df}=1,96, \mathrm{p}<0.982)$ in the catching efficiency of the Lethrinidae by hook type. Also, the difference in average catching efficiency between hook type and location was not significant (ANOVA: $\mathrm{F}_{\text {(hook type"locations) }}=0.001, \mathrm{df}=$ $2,96, \mathrm{p}<0.999)$. In addition, there was no significant difference in catching efficiency of the Lethrinidae catch among the three fishing locations (ANOVA: $F=2.366$, $\mathrm{df}=2,96, \mathrm{p}<0099$ ).

There was a significant difference in the average total catch weight of Lethrinidae by hook type (ANCOVA: F $=12.931, \mathrm{df}=1,352, \mathrm{p}<0.001)$. The circle hooks caught on average $36.3 \%$ by weight and $46.3 \%$ by number of the total combined catch. The Lethrinidae catch accounted for $59.6 \%$ by weight and $66.7 \%$ by number of the total combined catch (commercial and non-commercial). In all three locations and for both hook types, $63 \%$ of the total Lethrinidae catch were in the range of $31-60 \mathrm{~cm}$, 
$30 \%$ were $<31 \mathrm{~cm}$, and only $7 \%$ were $>61 \mathrm{~cm}$ in length. Between the hook types the length frequency distribution of Lethrinidae was significantly different $\left(x^{2}=\right.$ 22.783, df $=2, \mathrm{p}<0.001)$, with fewer small fish $(<31 \mathrm{~cm})$ caught by the J-hook and the circle hook caught more than expected Lethrinidae 31-60 cm. With respect to Lethrinidae larger than $61 \mathrm{~cm}$, both hook types caught similar numbers.

\section{Gross financial benefits from the commercial catch}

The total catch value of the commercial catch (excluding the protected (shark)Paragaleus sp. (Ducrocq 2004)) from both hook types was OMR 354 or $0.500 \mathrm{OMR} / \mathrm{kg}$ (1 Omani Rial (OMR) = US \$2.58, see Table 3 for details) and the share of the circle hooks is about $62 \%$ which is significantly different from the J-hooks $\left(\chi^{2}=7.501, \mathrm{df}\right.$ $=2, \mathrm{p}<0.024)$. The total catch value of Lethrinidae from both hook types was OMR 237.9 or $0.49 \mathrm{OMR} / \mathrm{kg}$. By hook type the value of the catch of Lethrinidae was significantly different at all three locations $\left(x^{2}=8.032\right.$, df 2 , $\mathrm{p}<0.018)$. At locations 2 and 3 the catch value for the circle hook was greater than that of the J-hook. The total value of the catch taken by the circle hook was $61 \%$, however on a value per kg basis there was little difference between hook types. Lethrinus microdon was by far the most dominant commercially valuable species caught by both hook types with a total catch value of OMR 135.4 (Table 3). There was no significant difference across all three locations in the catch value of Lethrinus microdon by hook type $\left(\mathrm{X}^{2}=5.186, \mathrm{df}=1, \mathrm{p}<0.075\right)$. The total catch of Lethrinus microdon from the circle hook accounted for $65 \%$ of the total catch value of this species. By location, the total catch value of this species, caught by the circle hook, was higher at all three locations.

\section{Time efficiency}

In relation to 'setting times' no significant difference was found in the time for either hook type (ANOVA: F = 0.397 , $\mathrm{df}=1,32, \mathrm{p}<0.533$ ) or between fishing locations (ANOVA: $\mathrm{F}=0.629$, df $=2,48, \mathrm{p}<0.537$ ). For both hook types at each location, the average setting time ( \pm standard error) was $6.8 \pm 0.2$ minutes. There was no significant difference in the time required to haul a longline of either hook type (ANOVA: $\mathrm{F}=2.269, \mathrm{df}=1,32, \mathrm{p}<0.141$ ) or between fishing locations (ANOVA: $\mathrm{F}=0.632, \mathrm{df}=2$, $48, \mathrm{p}<0.536)$. For both hook types at each location the average hauling time ( \pm standard error) was $14.3 \pm 0.4$ minutes.

\section{Discussion}

The results suggest that circle hook performs better than its counterpart in relation to various yardsticks. While the locational difference noted with regard to hook status, the overall finding from this study is in fa- vour of circle hook as more circle hooks retrieved with fish. This is consistent with the results obtained by Willey et al. (2016). Willey et al. (2016) found that circle hooks performed better than J hooks with regard to both hooking and capture rate. The economic implication of this finding is that circle hook has the potential to fishing success involving commercial species as indicated by the results of catch composition which can improve returns from fishing operations, other things being equal.

The proportion of retrieved J-hooks with bait attached was almost double the proportion of circle hooks with bait. This, perhaps, suggests that the baited J-hook may have been less attractive to fish because the shank of the hook is longer and more exposed. There was no indication of bait loss to seabirds, turtles or sea mammals. It is possible that small fish or crustaceans could have eaten the bait without being hooked. Also, this could be a result of the lack of experience of the crews in correctly baiting circle hooks, which may have resulted in poorer bait retention on the hook.

During the experiment both hook types were lost on occasion because of missing mainline section, missing branch lines, or missing hooks only. Compared to the J-hook, the circle hook had a relatively low proportion of gear loss which has direct bearing on the cost of fishing. One of the reasons for losing branch lines and hooks might relate to the characteristics of fishing locations, which are characterised by patchy regions of coral reefs and rocks. In contrast to the circle hook, the J-hook has an exposed point which may increase its potential for fouling on rocks and coral. The other reason might be related to sea conditions, which were unpredictable and fluctuated between calm and rough and thus resulted in high current tension on the gear.

Although this study was conducted after the monsoon season, generally regarded as a good fishing season, the numbers of commercial and non-commercial fish caught by both hook types at all three fishing locations were relatively lower than that from normal commercial fishing operations. The reasons for this low catch rate could be related to several factors including environmental factors (e.g. wind, current, temperature and depth), biological factors (e.g. species diversity, fish habitat preference), engineering factors (e.g. fishing gear constructions), and human factors (e.g. skill and experience of the skipper and crew) (Bjordal \& Lokkeborg 1996).

With regard to the total catch, where the commercial catch is significantly higher than the non-commercial catch, the effectiveness of the circle hook is significantly higher than the J-hook. The implication of this finding is that in the absence of any limit on output (that is, total allowable catch) in the fishery and given equal soak time for both hook types, the circle hooks are financially more desirable to fishers than J-hooks. This is, perhaps, one of the main reasons of circle hook increased popularity among traditional fishers in recent years. 
The significant difference in hooking location indicates that circle hooks cause less hooking damage than the J-hooks because a majority (98\%) of the fish caught by the circle hook were hooked in the corner of the mouth and jaw. findings from other studies (for instance, see (Grover et al. 2002, Lukacovic \& Uphoff 2002, Skomal et al. 2002). There are a number of claims in support of circle hooks with particular reference to hooking status, injuries (Cooke \& Suski 2004) and mortality (Muoneke \& Childress 1994). The circle hook increases survival because circle hooks predominantly catch in the jaw, whereas the J-hook catches more fish in the gut (Trumble et al. 2002). For example, in a study on red drum by Thomas et al. (1997), it was found that the hooking mortality rate for the circle hook was $3 \%$ and for the J-hook was $7 \%$. In investigating the capture efficiency and injury rate of walleyes circle Jones (2011) found that the strike-specific injury rate of circle hooks ( 0.12 injuries/ strike) was significantly lower than that of J hooks $(0.27$ injuries/strike). In assessing the role of circle hooks in conservation and fisheries management based on case studies and literature review Cooke \& Suski (2004) observed that the incidence of hooking mortality was considerable lower for circle hooks than J hooks. In a quantitative review of literature with particular reference to commercial and recreational hook-and-line fisheries Serafy et al.(2009) noted that higher rates of mortality, deep hooking and bleeding were associated with J-hooks relative to circle hooks. Because of relatively minimum injuries and less mortality rates (including incidence of bleeding and ease of hook removal) associated with circle hooks, the use of circle hooks was promoted as a potential conservation tool for both target and non-target species (Cooke et al. 2003; Kerstetter \& Graves, 2006; Andraka et al. 2013; Huang et al. 2016)

The economic implication is that fish caught with less physical damage by the circle hook remain fresh and are more likely to command a better market price (Hareide 1995) and hence better financial returns for traditional fishers. Kerstetter \& Graves (2006) argued that by reducing the catch of non-target and bycatch species the use of circle hook may also increase time efficiency by saving crew time and hence vessel operation costs. The management implication of this result is that the use of circle hooks may be encouraged by the management authority through a regulatory measure for conservation of fisheries resources that involve both target and non-target species. Andraka et al. (2016) mentioned that circle hooks have been proposed in nine Eastern Pacific Ocean countries as a way to mitigate the problem of sea turtles by-catch. The present study involves only three locations, and replication of this experiment is recommended to ensure the validity of the results and thus make effective management decisions.

The catching efficiency of the total catch (commercial and non-commercial) for both hook types was $16.9 \mathrm{~kg}$ per 100 hooks retrieved and the difference in catching efficiency between the circle hook $(17.1 \mathrm{~kg} / 100$ hooks retrieved) and the J-hook (16.7 kg/100 hooks retrieved) was not statistically significant. These figures are considerably higher than those reported by Pajot \& Weerasooriya (1980) in Sri Lanka (4.6 kg per 100 hooks) and by Kihedu et al. (2001) in Tanzania (5.8 kg per 100 hooks). The total catch (commercial and non-commercial) weight for circle hook was relatively higher than that of the J-hook. Although no significant difference methods found in total catch number among the two hook types, the same is not true for the total catch weight. This implies that, other things being equal, the higher catch weight offers higher revenue for fishers. With regard to the total catch value of the commercial catch the circle hook performed better than the J-hook. The average unit $(\mathrm{kg})$ price was also higher for the catch of the circle hook because more highly valued species where caught with this hook and fish were less damaged Thus circle hook has the potential of generating higher financial benefits to fishers. A comparative study by Özgül et al. (2015) on circle hook (kahle hook) and J-hook baited with sardine in the pelagic longline fishery of Turkey, it was found that the overall catch-per-unit-effort (CPUE) for all fishes involving circle hook was about two-times higher than that of J-hook.

\section{Conclusion}

This paper examines the performances of the circle hook and the J-hook generally used by the traditional Omani fishers for demersal longline fishing. The results from this experimental research suggest that the overall performance - measured with various operational yardsticks (i.e. hooking status and location, catch composition and quality, catching efficiency, and time and cost efficiency) - of the circle hook surpasses that of its counterpart. The results also indicate that the use of circle hook has the potential to yield better financial returns which is in harmony with one of the strategic goals -'to increase traditional fishers' income'- of the sector as stipulated in the 7th five-year plan (MNE, 2007). It is acknowledged that reliance only three fishing locations may restrict the scientific generalizations. Replication of this experimentation may help ensure the validity of the results and thus make effective management decisions. Also, there is a need to gather more evidence through further trial by varying the parameters of interest such as hook size and shape, bait type and size, water columns, location, and season to evaluate the efficiency and selectivity of longline gear.

At the same time, here is an opportunity to involve local fishers in such research activities which has the potential to play an important role in generating community awareness about the possible benefits of this type of research and in fostering community responsibility. 


\section{References}

Al-Masroori H, Al-Oufi H, McIlwain JL, McLean E. 2004. Catches of lost fish traps (Ghost fishing) from fishing grounds near Muscat, Sultanate of Oman. Fisheries Research 69: 407-414.

Andraka, S., Mug, M., Hall, M., Pons, M., Pacheco, L., Parrales, M., Rendón, L., Parga, M.L., Mituhasi, T., Segura, Á. and Ortega, D., 2013. Circle hooks: Developing better fishing practices in the artisanal longline fisheries of the Eastern Pacific Ocean. Biological Conservation, 160, pp.214-224.

Bach P, Dagorn L, Misselis C. 2000. The role of bait type on pelagic long line efficiency, ICES, Copenhagen (Denmark). p.16.

Bjordal A, Lokkeborg S. 1996. Longlining, Fishing News Books, Osney Mead, Oxford, England.

Bjordal A. 1988. Recent developments in longline fishing: catching performance and conservation aspects, Institute Fisheries Technical Research. pp. 19-23.

Bjordal A. 2002. The use of technical measures in responsible fisheries: regulation of fishing gear. In: Cochrane KL, editor. A fishery manager's guidebook. Management measures and their application. FAO Fisheries Technical Paper. No. 424. Rome, FAO. 231p.

Cai J, Leung PS, Pan M, Pooley S. 2005. Economic linkage impacts of Hawaii's longline fishing regulations, Fisheries Research 74: 232-42.

Clarke M, Borges R, Stokes D. 2002. Comparisons of trawl and longline catches of deep water Elasmobranches West and North of Ireland, Scientific council meeting, NAFO SCR. Doc. 02/27, Serial No. N 4749.

Cooke, S.J., Suski, C.D., 2004. Are circle hooks an effective tool for conserving marine and freshwater recreational catch-and-release fisheries?. Aquatic Conservation: Marine and Freshwater Ecosystems, 14(3), pp.299-326.

Cooke, S.J., Barthel, B.L. and Suski, C.D., 2003. Effects of hook type on injury and capture efficiency of rock bass, Ambloplites rupestris, angled in south-eastern Ontario. Fisheries Management and Ecology, 10(4), pp.269-271.

Ducrocq M. 2004. A $6,000 \mathrm{~km}^{2}$ coastal sanctuary for sharks and rays in Mauritania, West Africa, Fondation Internationale du Banc d'Arguin, France, Shark News, p. 15, http://128.227.186.212/fish/organizations/ssg/sharknews/sn16/sn16.pdf, accessed 28 October 2006.

Garry L, Preston GL, Mead PD, Chapman LB, Taumaia P. 1999. Deep-bottom fishing techniques for the $\mathrm{Pa}$ cific Islands: A manual for fishermen, Secretariat of the Pacific Community, Print, New Zealand.

Grover AM, Mohr M, Plamer-Zwahlen M. 2002. Hook- and-release mortality of Chinook salmon from drift mooching with circle hooks: Management implications for California's ocean sport fishery, In: Lucy, JA, Studholme AL, editor. 2002. Catch and release in marine recreational fisheries, American Fisheries Society Symposium 30: 39-56.

Halliday R, Kenchington TJ. 1993. Size selection of ground fish longline gear, Project Summary. Fisheries and Ocean, Scotia-Fundy Region, Halifax, Nova Scotia, No. 40, p. 5.

Hareide NR. 1995. Comparison between longlining and trawling for deep water species selectivity, quality and catchability-A review. In: Hopper AG, editor. deep water fisheries of the North Atlantic Slope, pp. 227-234.

He X, Bigelow KA, Boggs CH. 1997. Cluster analysis of longline sets and fishing strategies within the Hawaii-based fishery, Fisheries Research 31: 147-158.

Huang, H.W., Swimmer, Y., Bigelow, K., Gutierrez, A. and Foster, D.G., 2016. Influence of hook type on catch of commercial and bycatch species in an Atlantic tuna fishery. Marine Policy, 65, pp.68-75.

ICES. 1977. Report of the working group on standardisation of scientific methods for comparing the catching performance of different fishing gear, Cooperative research report No. 66, International Council for the Exploration of the Sea Charlottelund slot, DK-2920 Charlottenlund, Denmark, pp. 16.

Johannessen T, Ferno A. Lokkeborg S. 1993. Behaviour of cod (Gadus morhua) and haddock (Melanogrammus aeglefinus) in relation to various sizes of longline bait, ICES, Marine Science Symposia 196: 47-50.

Jones, T.S., 2005. The influence of circle hooks on the capture efficiency and injury rate of walleyes. North American Journal of Fisheries Management, 25(2), pp.725-731.

Kerstetter, D.W. and Graves, J.E., 2006. Effects of circle versus J-style hooks on target and non-target species in a pelagic longline fishery. Fisheries Research, 80(23), pp.239-250.

Kihedu KJ, Mlay MKL, Mwambungu JA, Ngatunga B.P. 2001. Proceedings Drifting Long Line, A Potential Fishing Method for the Northern Part of Lake Nyasa/ Malawi/Niassa, Tanzania Fisheries Research Institute, Kyela Centre, East Africa, Lake Malawi Fisheries Management Symposium.

Lokkeborg S, Bjordal A. 1992. Species and size selectivity in longline fishing, a review, Fisheries Research 13: 311-322.

Lukacovic R, Uphoff J. 2002. Hook location, fish size and season as factors influencing catch and release mortality of striped bass caught with bait in Chesapeake Bay. In: Lucy JA, Studholme AL, editor. Catch and Release in Marine Recreational Fisheries, American 
Fisheries Society Symposium, vol. 30, pp. 97-100.

MAF. 2002. Longline fishery in Oman, Ministry of Agriculture and Fisheries, Sultanate of Oman, Unpublished report.

MAF. 2013. Fisheries Statistics Book for 2013, Directorate general of planning and development, Ministry of Agriculture and Fisheries, Sultanate of Oman.

Martian WR, McCracken FD. 1954. Relative efficacy of baits for groundfish, Program Report Atlanta Biological Sta. 126: 17-20.

MNE. 2004. Selected Data and Indicators from (1993 \& 2003) Censuses, Census Administration, Ministry of National Economy, Sultanate of Oman.

MNE. 2007. Seventh five-year development plan 20062010, Ministry of National Economy, Ministry of National Economy, Sultanate of Oman.

Muoneke MI, Childress WM. 1994. Hooking mortality: a review for recreational fisheries, Reviews in Fisheries Science 2: 123-156.

Özgül, A., Ulaş, A., Lök, A., Düzbastılar, F.O. and Metin, C., 2015. A Comparison of Alternative Circle Hook (Kahle Hook) and J Style Hook Performance in Experimental Pelagic Longline Fishery in Turkey. Turkish Journal of Fisheries and Aquatic Sciences, 15(1), pp.19-27.

Pacheco, J. C., Kerstetter, D. W., Hazin, F. H., Hazin, H., Segundo, R. S. S. L., Graves, J. E. \& Travassos, P. E. 2011. A comparison of circle hook and J hook performance in a western equatorial Atlantic Ocean pelagic longline fishery. Fisheries Research, 107(1-3), 39-45.

Pajot G, Weerasooriya KT. 1980. Fishing trials with bottom set longlines in Sri Lanks, Food and Agriculture Organisation of the United Nations, Development of Small-Scale Fisheries in the Bay of Bengal, Madras, India.

Prince, E. D., Ortiz, M., \& Venizelos, A. 2002. A comparison of circle hook and "J" hook performance in recreational catch-and-release fisheries for billfish. In American Fisheries Society Symposium (pp. 66-79). American Fisheries Society.

Radcliffe C. 2005. Fishing system technologist: a handbook for fisheries extension workers, Ministry of Agriculture and Fisheries, Sultanate of Oman, p.181.

Serafy JE, Cooke SJ, Diaz GA, Graves JE, Hall M, Shivji M. Swimmer Y. 2012. Circle hooks in commercial, recreational, and artisanal fisheries: Research status and needs for improved conservation and management, Bulletin of Marine Science 88(3): 371-391.

Serafy, J.E., Kerstetter, D.W. and Rice, P.H., 2009. Can circle hook use benefit billfishes?. Fish and Fisheries, 10(2), pp.132-142.

Skomal GB, Chase BC, Prince ED. 2002. A comparison of circle hook and straight hook performance in rec- reational fisheries for juvenile Atlantic Bluefin Tuna, In: Lucy JA, Studholme AL, editor. 2002. Catch and release in marine recreational fisheries, American Fisheries Society Symposium 30: 57-65.

Skud BE, Hamley JM. 1978. Factors affecting longline catch and effort: II. Hook spacing, International Pacific Halibut Commission Scientific Report 64: 15-24.

Stengel H, Al-Harthy A. 2001. First investigation about the efficiency of bottom longlining in the EEZ of the Sultanate of Oman (Masirah Area), Ministry of Agriculture and Fisheries, Unpublished report.

Thomas RG, Boudreaux C, Lightner J, Lear E, Hebert V. 1997. Hook release mortality of red drum and spotted sea trout. Abstract in the 1997, Southern Division American Fisheries Society Midyear Meeing, San Antonio, TX.

Trumble RJ, Kaimmer SM, Williams GH. 2002. A review of the methods used to estimate, reduce, and manage bycatch mortality of pacific halibut in the commercial longline ground fish fisheries of the Northeast pacific, In: Lucy JA, Studholme AL, editor. 2002. Catch and release in marine recreational fisheries, American Fisheries Society Symposium 30: 88-96.

Willey, A.L., Barker, L.S. and Sampson, M., 2016. A comparison of circle hook and J hook performance in the recreational shark fishery off Maryland. Fishery Bulletin, 114(3), pp.370-373. 